\section{Reallocate funds to boost performance}

Last month's report by the Council of Canadian Academies, prepared at the government's request, reveals that Canada's research output and impact rank seventh and sixth in the world, respectively (see go.nature.com/ pyvwlk). Shouldn't the country be performing better, given its sustained investment in research and development (R\&D)?

Gross domestic expenditure on $\mathrm{R} \& \mathrm{D}$ by the government and higher-education sectors was $0.77 \%$ of gross domestic product (GDP) in 2008 and has been maintained throughout the global financial crisis $(0.79 \%$ in 2010). Although Canada performs well given its small population, its GDP is relatively high because of natural-resource exports, so these figures may be underestimates. Its $2008 \mathrm{R} \& \mathrm{D}$ investments exceeded those of Japan and of every European Union member except Finland and France (see go.nature. com/59dg8f).

Canadian academia can improve returns on this public investment. Stimulating competition and responsibility for delivering research output and impact would support the government's commitment to fiscal accountability. For example, it could assess researchers every $5-10$ years and reallocate a small amount of existing public funding to the highest performers. These measures could bring Canada in line with other developed countries, such as the United Kingdom and Australia. Andrew J. Tanentzap York University, Toronto, Canada. atanzap@yorku.ca

\section{Social insight rings true 125 years on}

David Rand and colleagues pose the question: "Are we intuitively cooperative, with reflection upon the logic of self-interest causing us to rein in our cooperative urges and instead act selfishly?" (Nature 489, 427-430; 2012). In answering affirmatively, they confirm an observation made 125 years ago by the Republican Senator for California, Leland Stanford.

Stanford had introduced a bill to foster worker cooperatives in 1886, and was interviewed by The Cincinnati Enquirer. When Stanford broached the issue of women's rights, the reporter asked him, "Do you not think women will go off on sentimental issues if they undertake the business of government and break up the organizations by which men work out large ends?” Stanford replied, "Oh! It is not sentiment that we have to fear so much as we suppose. A man's sentiments are generally just and right, while it is second selfish thought which makes him trim and adopt some other view. The best reforms are worked out when sentiment operates, as it does in women, with the indignation of righteousness." (See go.nature. com/i6b91d.)

Stanford's discernment of rapid, pro-social sentiment and slower, selfish calculation is but one part of a larger body of thought on the potentials for cooperation in the economy, which we may find worth revisiting today.

Lee Altenberg Maui, Hawaii, USA.

altenber@hawaii.edu

\section{Beit fellowships forge a Nobel link}

The Beit Memorial Fellowship scheme, the first specifically to support young UK medical researchers, has made a remarkable contribution to British biomedical science over the past 100 years. John Gurdon's Nobel prize this year (see go.nature.com/yo3cxf) is the seventh to be awarded to a former Beit fellow.

Other Nobel laureates who once held Beit fellowships were Alexander Todd (chemistry, 1957), Fred Sanger (chemistry, 1958 and 1980), Macfarlane Burnet (physiology or medicine, 1960), Bernard Katz (physiology or medicine, 1970) and Tim Hunt (physiology or medicine, 2001). Some $10 \%$ of Beit fellows have gone on to become fellows of the Royal Society, including Marjory Stephenson (1914 Beit fellowship), who became one of the first two female Royal Society fellows in 1945.

The scheme merged with the Wellcome Trust Intermediate Fellowship in 2009 to create the Wellcome-Beit Prize Fellowships (see go.nature.com/i2tofa).

Andrew McMichael Weatherall Institute of Molecular Medicine, University of Oxford, UK. andrew.mcmichael@imm.ox.ac.uk Cyril Chantler UCL Partners Academic Health Science Partnership, London.

\section{Timely reminder to return to the Moon}

The death of astronaut Neil Armstrong (see Nature 489, 368 ; 2012) reminds us that, 43 years after he set foot on the Moon, the satellite is still a hot target.

It is the best and most accessible place in the Solar System for robotic and human assets to address fundamentally important scientific questions while expanding our technological capabilities. Most of the Moon remains unexplored: we have never been to its far side, or to its polar regions.

In the last year of his life, Armstrong told a committee appointed by the US Congress that the larger humanexploration goals lie beyond low Earth orbit, namely: "Luna, the lunar Lagrangian points, Mars and its natural satellites, and near-Earth objects including meteoroids, comets and asteroids". He went on: "Last year
I testified to this committee on the rationale for selecting Luna and its environs as the preferred initial option for America's exploration beyond Earth orbit. All that I have learned in the past year has just reinforced that opinion."

Let's hear and act on those words. Rather than exploring new options, we should begin building the hardware, selecting the landing sites, training the crews and planning the details of missions that take us to the Moon and a future of new discoveries.

David A. Kring Universities Space Research Association, Lunar and Planetary Institute, Houston, Texas, USA.

kring@lpi.usra.edu Jack O. Burns University of Colorado Boulder, Colorado, USA. D. Ben J. Bussey Johns Hopkins University Applied Physics Laboratory, Laurel, Maryland, USA.

Competing financial interests declared; see go.nature.com/4exu7l.

\section{Bureaucracy bypass let research flourish}

The remarkable success of the UK Laboratory of Molecular Biology in Cambridge (W. Bynum Nature 490, 31-32; 2012) might be explained in the words of Max Perutz. When asked what makes creative research, he would say: "No politics, no committees, no referees, just talented highly motivated people" (G. Radda Nature Med. 8, 205; 2002).

Four of the greatest discoveries of the twentieth century - the structure of the atom, quantum mechanics, the theory of relativity and the structure of DNA - were made without project reviewers or grant-giving agencies (B. Gal-Or Cosmology, Physics, and Philosophy p. 493; Springer, 1983). Min-Liang Wong College of Veterinary Medicine, National Chung-Hsing University, Taichung,Taiwan. mlwong@dragon.nchu.edu.tw 